\title{
Kisar, a small island participant in an extensive obsidian network in the Wallacean Archipelago
}

\author{
Christian Reepmeyer ${ }^{1,3}$, Sue O’Connor ${ }^{2,3}$, Mahirta $^{4}$, Shimona Kealy ${ }^{2,3}$, Tim Maloney \\ ${ }^{1}$ College of Arts, Society and Education, James Cook University, Cairns, Australia \\ ${ }^{2}$ ARC Centre of Excellence for Australian Biodiversity and Heritage, Australian National University, \\ Canberra 2601, Australia \\ ${ }^{3}$ Archaeology \& Natural History, College of Asia and the Pacific, Australian National University, \\ Australia \\ ${ }^{4}$ Departemen Arkeologi, Fakultas Ilmu Budaya, University of Gadjah Mada, Yogyakarta, Indonesia. \\ ${ }^{5}$ Griffith University
}

Key words: obsidian, maritime transport, exchange, risk buffering, Indonesian islands

\begin{abstract}
Here we report the results of a pXRF analysis of obsidian stone artefacts from Here Sorot Entapa rockshelter (HSE) on Kisar Island in the Wallacean Archipelago. With the exception of a single flake, all the obsidian artefacts in this site are from a single source. Kisar has a metamorphic geology with fringing uplifted limestone terraces (Agustiyanto et al. 1994) which makes obsidian raw material exotic to the island. The Kisar obsidian is a chemical match to obsidian of an unknown source previously recovered from sites in Alor Island to the west, and which also appears in Timor Leste to the south. The obsidian results suggest that Kisar was receiving exotic obsidian from $\sim 15,000$ years ago, and was linked with Alor and Timor in a maritime exchange network from at least 13,000 years ago.
\end{abstract}




\section{INTRODUCTION}

The timing, extent and sustainability of small island colonisation is an ongoing debate in Archaeology (Dawson 2014, Keegan et al. 2008). It is a widely accepted hypothesis that small islands were colonised both later and less intensively than larger islands, because of the reduced availability of subsistence resources (Fitzpatrick et al. 2016). Albeit, the hypothesis that islands with a depauperated terrestrial environment were only permanently colonised with the arrival of agricultural societies has lately been disproven (O'Connor et al. 2018). Archaeological evidence from the Mediterranean (Dawson 2014) and Island Southeast Asia (ISEA) shows a later colonisation (Tanudirjo 2005, Bellwood et al. 1998) and permanent resident populations of at least some small islands; as shown by the new data from the small island of Kisar, eastern Indonesia, suggesting a relatively late colonisation at 15,000 years ago (O’Connor et al. 2018).

However, it remains unclear what processes enabled past communities to access small islands and sustain populations on them. Reepmeyer et al. (2016) argued for the start of more intensive interaction networks being established in the terminal Pleistocene when sea-level rise increased productivity of coastal habitats in ISEA. This was evidenced by the maritime transportation of obsidian raw material which might indicate a high frequency of inter-island movement of people and materials. The new data presented in this report support this hypothesis.

We present data from the Here Sorot Entapa rockshelter (HSE) on the small island of Kisar in eastern Indonesia which was first occupied about 15,000 years ago (O’Connor et al 2018). The shelter deposit contains dense subsistence material comprised almost exclusively of marine resources such as fish, crustacean, urchins and shellfish as well as a diverse repertoire of material culture including a range of shell fish hooks and beads, a fish hook file made of coral, and stone artefacts of obsidian, quartz and chert. 
The obsidian stone artefacts must be exotic to the island and obtained via maritime exchange, and it has been argued previously that it was only the existence of such a network that would have allowed the colonization and occupation of islands of this size.

\section{BACKGROUND}

Figure 1: Map of Lower Sunda Islands with the Here Sorot Entapa rockshelter location.

Kisar lies approximately $25 \mathrm{~km}$ north east of the island of Timor and is part of the Indonesian province of Maluku Barat Daya (Figure 1). It is an emergent island in the hinterland of the active Banda arc-continent collision zone. Today Kisar is ca. $10 \times$ $8.7 \mathrm{~km}$ with a total area of $81.15 \mathrm{~km}^{2}$. It has a narrow coastal platform owing to its rapid rate of uplift and deep offshore profile. The steep offshore profile means that its land area has changed little during the sea level fluctuations of the past 50,000 years. Even

during periods of maximum low stand, it would never have been much larger than it is today. Kisar originated from uplifting, high-pressure metamorphic rocks that formed through the collisional deformation of the India-Australian Plate-Banda Sea Plate interaction (Hall 2002; Major et al. 2013). While the metamorphic core of Kisar first emerged ca. 450k years ago (Major et al. 2013), the island is almost completely encircled by a series of Quaternary, coralline limestone terraces that run parallel to the coastline (Agustiyanto et al. 1994; Major et al. 2013). The rockshelter known as Here Sorot Entapa is formed in these limestone terraces. The uplifted limestone terraces create steep, almost vertical cliffs girting large parts of the island, and easy access to the sea is available in only a few areas. A high energy beach about $135 \mathrm{~m}$ west of HSE provides one of the few access points along this section of the coastline.

THE HERE SOROT ENTAPA EXCAVATION 
Here Sorot Entapa (HSE) was excavated by a joint Australian-Indonesian team over one field season in September 2015. HSE is located approximately $100 \mathrm{~m}$ from the coast and about $24 \mathrm{~m}$ above mean sea level on the south coast of Kisar, facing Timor Leste (Figure 1). The site comprises a shelter about $12 \mathrm{~m}$ in length at its widest point, and $10 \mathrm{~m}$ in depth from the back wall to the dripline (Figure 2). The wall of the shelter opens into an enclosed chamber with a dome roof (approximately 5 meters high) that is on average $9 \mathrm{~m}$ deep from the opening to the back wall and about $6 \mathrm{~m}$ across. Painted rock art occurs on the walls of the shelter near the entrance (O'Connor et al. 2017).

Figure 2: Plan of the HSE shelter and cave with excavation indicated in yellow and large rocks/boulders in blue.

Two $1 \times 1 \mathrm{~m}^{2}$ test pits (Squares A and B) were excavated in the main shelter floor outside the cave entrance but within the dripline (Figure 2). Both were excavated in 5 cm spits within sedimentary units. Square A was excavated to a depth of $1.3 \mathrm{~m}$ and Square B to a depth of $1.2 \mathrm{~m}$, when natural coralline rubble and sand was encountered. The site preserves abundant subsistence evidence consisting predominantly of fish bone. The fish were procured from the reefs and inshore waters surrounding the island using a range of finely made fish hooks which are found throughout the sequence. Crustaceans, shellfish, and urchins were also dietary staples collected from the rocky shoreline or coral reef. A small quantity of tetrapod fauna was recovered and consisted of marine turtle, fruit bats, small bats, rats and reptiles (O’Connor et al. 2018). 
Figure 3: Stratigraphy of HSE, Square A and B. Stratigraphic units numbered with the image, spits numbered down the vertical axis.

The stratigraphy of HSE rock shelter has been described in detail in O'Connor et al. (2018). The deposit is composed of nine Stratigraphic Units. Radiocarbon dating of shell and charcoal samples removed from the walls indicate that the stratigraphic units are similar in age across the site (Figure 3). The deposit can be divided into two broad chronological phases. Phase 1 begins with initial occupation around 15,000 years ago and continues into the early Holocene 9500 years ago. This phase includes stratigraphic Units 2 to 6 (Spits 22 to 7), and is characterized by the abundance of siliceous chert and the presence of obsidian. The second phase of occupation commences about 4900 years ago and continues until about 1800 years ago or more recently. Phase 2 includes stratigraphic Units 7 to 9 (Spits 6 to 1), and is characterized by an abundance of crystal quartz and the presence of pottery. Between these two phases, specifically between stratigraphic Units 6 and 7, there appears to have been a temporal hiatus in human occupation. The multiphase Bayesian model of the dates reported in O'Connor et al. 2018 and likely unit terminals support this hiatus in the record, with a lack of overlap between the modelled end date for Unit 6 and start date for Unit 7.

HSE ARTEFACTS

A total of 3703 flaked stone artefacts were recovered from the two excavation squares, with most found in Square B, likely due to its more central location in the living floor of the shelter $(A=744, B=2959)$. The dominant raw material is a siliceous chert, which geologically may occur in the limestone on Kisar. No source has yet been identified. Crystal quartz was also occasionally exploited, with a major shift in preference in the 
upper mid to late Holocene part of the sequence when obsidian drops out of the assemblage. The total number of artefacts [TNA] and the minimum number of flakes $[\mathrm{MNF}]$ show the same unimodal peak indicating that the increase in numbers of artefacts at this time is unrelated to breakage (Figure 4).

Figure 4: Lithics graph histogram. Artefact frequencies A) Square A TNA and MNF values B) Square B TNA and MNF values C) Raw material types Square A D) Raw material types Square B.

One hundred and ninety-three obsidian artefacts were recovered in Square B. Obsidian artefacts appear in the earliest deposits (Spit 23), but have a discrete peak in deposition between Spits 19 and 16 ( $70 \%$ of all obsidian artefacts were found in Spits 17$)$, coinciding with the general increase in stone artefacts and other cultural materials. Obsidian was infrequently deposited in Square A $(n=2$, Spit 8). There is unimodal discard peak with most artefacts concentrated within the ashy and shell rich Unit 3 (Spits 16 and 12 in Square A, and Spits 17 and 12 in Square B).

\section{RESULTS}

Artefacts were selected by size and only artefacts larger than the threshold of covering the complete X-Ray beam ( $\sim 6 \mathrm{~mm}$ diameter) were analysed; 108 artefacts were rejected based on size. In this study, minimum thickness requirements of the artefact were dismissed, taking into account increased variability in the calculated elemental concentrations. In total, 86 obsidian artefacts excavated from Square B and one artefact from Square A at HSE were analysed. Comparing total number of artefacts per spit to analysed artefacts per spit, no sampling bias was detected.

The artefacts were geochemically fingerprinted by portable X-Ray Fluorescence 
analysis (pXRF) with a Bruker Tracer III-SD. Manufacturer recommended settings of $40 \mathrm{keV}$ and $42 \mathrm{~mA}$ were employed using a $0.1524 \mathrm{~mm} \mathrm{Cu}, 0.0254 \mathrm{~mm}$ Ti and 0.3048 mm Al filter in the X-Ray path and a $60 \mathrm{~s}$ live-time count at 145 FWHM setting. The raw counts of the pXRF were calibrated using 40 international standards provided by MURR (Glascock and Ferguson, 2012). Each artefact was analysed at two spots and the averages are presented Supplementary Table 1. Element concentration of manganese $(\mathrm{Mn})$, iron $(\mathrm{Fe})$, zinc $(\mathrm{Zn})$, gallium $(\mathrm{Ga})$ thorium $(\mathrm{Th})$, rubidium $(\mathrm{Rb})$, strontium $(\mathrm{Sr})$, yttrium $(\mathrm{Y})$, zirconium $(\mathrm{Zr})$ and niobium $(\mathrm{Nb})$ were calculated.

Geochemical sourcing of artefacts was conducted against identified sources from southern Wallacea, including original data from two sources, which have so far only been found in rockshelter sites in the region (Group 1 and Group 2, Reepmeyer et al. 2016).

Figure 5: Google Earth ${ }^{\mathrm{TM}}$ Map locations of the Kulutan sources. Detailed image of obsidian nodules in olivine-rich basalt matrix.

The reference dataset used in this study includes new information of the assumed local source on Alor Island, previously named Group 3 source (Table 1). This source was identified in primary deposition on the southern side of Alor Island close to the village Kulutan (Figure 5). Samples were taken in primary deposition from a very fine-grained olivine-rich basalt with occasional obsidian clasts embedded. Raw material was not detected in creek deposits at this location but the topography at the site has changed significantly because of road-building activities; the possibility of secondary find spots cannot be excluded. Although all samples derive from the same geological formation, they were found in different elevations suggesting that they represent several discrete, 
but related, volcanic events. The samples show that all of the three sub-sources identified by Reepmeyer et al. (2016: 25, Table 1) as belonging to Group 3 originate from the same source location. These sub-sources were predominantly separated by Rb and $\mathrm{Sr}$ abundances and nodules from the creek show both higher $\mathrm{Rb} /$ lower $\mathrm{Sr}$ (Kulutan-A, Group 3a) and lower Rb / higher Sr (Kulutan-B, Group 3c) abundances. Group 3b (Kulutan-C) which had strong similarities in mid-Z elemental concentrations to Group 3a (Kulutan-A), but showed low Fe values, also originates from this source location.

Table 1: Summary statistics of obsidian raw materials and reference standards.

Multi-variate statistics using discriminant function analysis of the geochemical results from HSE show a dominant utilization of Group 1 obsidians $(n=85)$. A single artefact in Spit 17 (HSE-B17-26) was tentatively sourced to Group 2 (Figure 6). Discriminant function analysis was not able to clearly attribute the artefact to Group 2 because of higher Mn and Fe values. However, limiting the analysis to selected elements which discriminate the three locations well, the artefact plots in the range of Group 2 source.

Figure 6: Discriminant function analysis of three obsidian sources from the area. Including Group 1 and 2 artefacts, for which the location of the outcrop is unknown and the Kulutan sources (previously Group 3a-c).

The source location of these two groups is currently not known (Reepmeyer et al. 2011, 2016), but it is assumed that obsidian is not local to Kisar as the island has no history of volcanism (Major et al. 2013). Group 1 obsidian is relatively abundant in sites on 
Alor Island, for example in the Tron Bon Lei site where both locally sourced rocks and exotic raw materials have been found, and it has also been found in small numbers in coastal Timor Leste sites (Ambrose et al. 2009, Reepmeyer et al. 2011). In view of its temporal and geographic distribution, in addition to the material quality and lack of a cortex on the artefacts, Group 1 obsidian is not believed to originate in either Alor or Timor Leste (Reepmeyer et al. 2016). Group 2 obsidian is assumed to be local to Alor Island based on the abundance of this source in sites on the island (Reepmeyer et al. 2016, and Abdillah Irfan pers. comm.), however, only further geological survey on Alor will enable us to unambiguously verify this.

Reepmeyer et al. (2016) suggested that the identified obsidian exchange network was limited to the exploitation of Group 1 obsidian, as no other obsidian source other than Group 1 was found distributed on multiple islands. The identification of Group 2 obsidian on Kisar suggests that this obsidian source was also part of the exchange network. It appears that Group 2 obsidian was not transported to Kisar in the earliest period, based on the sample size of artefacts of initial deposition, however, there is a possibility that obsidian artefacts below the analysis threshold in the lower levels may represent Group 2 raw material. It is assumed that Group 2 obsidian started to become part of the exchange network when we see an intensification of obsidian transportation in Spit 17.

\section{DISCUSSION}

The HSE assemblage thus indicates that obsidian from a source external to the island appears with the earliest occupation. In neighbouring Timor Leste obsidian from an offisland source also appears in a number of sites after 15,000 years ago. In Jerimalai (Asitau Kuru), a shelter at the eastern end of Timor with an occupation record extending

to 42,000 years ago, the obsidian occurs in excavation units bracketed by dates of 
15,000 to 4000 years ago (Reepmeyer et al., 2011; Shipton et al. in press). At Laili in northern Timor Leste, where the deposits date between approx. 44,000 and 11,000 years ago, the only two obsidian artefacts were found in a unit dated between 15,000 and 11,000 years ago. In Tron Bon Lei in Alor, obsidian with the same geochemical signature as the Timor Leste artefacts occurs in layers post-dating 12,000 years ago (Reepmeyer et al. 2016).

HSE was reoccupied in the mid Holocene at which time there appears to have been a change in raw materials used for stone artefact manufacture as well as in the range of fish caught. Quartz dominates the stone artefact assemblage in Phase 2 and obsidian is absent above Spit 7 in Square A and Spit 5 in Square B, perhaps indicating the cessation of the maritime exchange network during the late Holocene occupation.

The HSE obsidian cores and flakes are of extremely small size, raising the question of what such small artefacts may have been used for, and why so much effort was expended on their maritime transport when other raw material was available. At Tron Bon Lei B in Alor Island obsidian artefacts in Groups 1, 2 and 3 were similarly characterised by miniaturisation. While retouched obsidian flakes were rare in the Tron Bon Lei B assemblage, some cores had small step terminating scar build-ups oriented perpendicular to the flaking axis which Maloney et al. (2018:86) argued likely indicated their use as tools for some specialised function. Although there is no evidence for deliberate retouch on the obsidian flakes from HSE, perhaps they were utilised for the extremely sharp working edge provided by this raw material. The increase in crystal quartz flakes (a hard glassy raw material which also produces a very sharp working edge), in the mid to late Holocene, when obsidian declines and then disappears, may indicate that quartz provided a substitute for obsidian for some specialised function 
after the maritime exchange network ceased. Future analysis of the HSE artefacts should include an assessment of use wear.

Reepmeyer et al. (2016) argued that the sustained inter-island maritime connectivity in Wallacea beginning about 15,000 years ago correlates with periods of increased post glacial sea-level rise. At the end of the Last Glacial Maximum sea-level rose in a series of very rapid episodes alternating with two periods of relatively stable sea-levels around $16,000-15,000$ years ago and 12,000 - 11,000 years ago. By $\sim 17,000-14,500$ years ago the sea-level had risen by $20 \mathrm{~m}$, which was the precursor to the Meltwater Pulse A1 (MWP-1A) between 14,500 - 14,000 years ago when sea-level rose on average 20 $\mathrm{m}$ in only 500 years. During the Younger Dryas sea-level rise slowed but never reversed, and reverted to a rapid pace after 11,000 years ago until current sea-level was reached around 7000 years ago (Lambeck et al. 2014). Parallel to the episodic nature of sealevel rise, the loss of landmass during the Terminal Pleistocene was not equally distributed throughout ISEA (Voris 2000). The drowning of the continental shelves to the west and south of the islands of Wallacea might have been a catastrophic event for populations living in these environments (Oppenheimer 1998), however, it is unlikely we can up-scale human behavioural responses in these areas to the region as a whole. This is due to coastlines in Wallacea showing significant variability with many islands having a particularly steep bathymetry (Hawkins et al. 2017) and variable uplift rates across Wallacea (Kealy et al. 2018). In some cases, for example, Alor Island, postglacial sea level rise divided a single large island into numerous smaller islands (O'Connor et al. 2017: 1452-3), however, the loss of land area may have been more than compensated for by the increased length of coastline around the combined newly created islands; a significant advantage for humans with a focus on maritime resources, living on islands with few terrestrial faunal resources (Shipton et al. in press). Research 
has shown that in the case of maritime resource use, populations showed substantial resilience during this period in that they maintained their maritime subsistence base without change (Pawlick et al. 2014, Samper-Carro et al. 2016). Reepmeyer et al. (2016) suggested that increased maritime interaction and social connections between populations on different islands may have followed on as a consequence of coastal communities pursuing maritime subsistence more intensively, as rising sea-levels increased the productivity in marine environments (Woodroffe et al. 2000). Incentives for inter-island travel may have also been found in the desire to maintain social bonds between clan or language groups who found themselves separated from kin (now resident on the newly created adjacent islands) by rising seas (Shipton et al. in press). Finally, inherently risky endeavours such as establishing settlements on resource-poor islands necessitated an increased investment in social relations, which could act as a buffer to minimise loss in the event of catastrophic failure of colonisation. These social networks can be seen as 'insurances' to reduce the effects of resource shortages through forms of social storage (Cashdan 1985; Wiessner 2002). It has been shown that in these cases social storage would enable return voyages and the re-integration of populations in founding societies.

This interpretation is strongly supported by the data from Kisar, which was likely first settled during this period of widespread maritime interaction. Prior to ca. 15,000 years ago, connections between Kisar and neighbouring islands appear to have been too tenuous to support a permanent occupation of this tiny island (O’Connor et al. in press). It comes at a time when we see the appearance of fully ground woodworking tools, such as shell adzes (Pawlick et al., 2015, Shipton et al. in press), indicating a specialisation and maybe an increase in the manufacture of dugout canoes and other watercraft. Fully ground stone adzes are so far only associated with Neolithic 
communities in ISEA (Bellwood 2011). However, they only show a marginal advantage in durability of working edges and shell adzes have been utilised for canoe building into the late Holocene in the Pacific, even when appropriate stone raw material alternatives were available (Bayman 2003).

\section{CONCLUSION}

The archaeological sequence in HSE shelter demonstrate that the small island of Kisar was occupied by at least 15,000 years ago. Kisar is extremely depauperate in terrestrial fauna and subsistence remains at the site indicate that protein was acquired almost exclusively from the sea. We have argued elsewhere on the basis of the diverse material culture subsistence evidence at HSE that settlement on Kisar was permanent (O’Connor et al. 2018). However, the presence of obsidian artefacts, a raw material not available on Kisar, demonstrates the presence of a maritime exchange network operating between Kisar and other islands in the Archipelago. The Kisar obsidian is predominantly from a single as yet unknown source, Group 1, which is not derived from Timor, the closest island to Kisar, or from Alor Island where it is found in relative abundance in the Tron Bon Lei sites. One flake identified as Group 2 obsidian which is also found in Tron Bon Lei was suggested to derive from an unknown source on Alor. If we are correct, several different islands contain obsidian sources that fed the exchange network which began about 15,000 years ago. Locating the obsidian sources for Groups 1 and 2 should be a priority for future research in this region.

We have recently argued that this type of maritime interaction network would have constituted a risk buffering strategy, providing relationships of reciprocity which were vital to ensuring that the population on a small island like Kisar could relocate in the event that water shortage or catastrophic damage to marine resources rendered the island uninhabitable. Some such catastrophe may have occurred around 9500 years ago 
when the HSE shelter ceased to be used. Why HSE was abandoned from the early to mid-Holocene is currently unclear and it is also uncertain whether occupation of the island or only the shelter ceased at this time. HSE was reoccupied approximately 5000 years ago and continued in use until about 1800 years ago. Imported obsidian is not found in the upper layers of the site where potsherds appear and occupation evidence is less dense. It seems likely that at this time people in Kisar were living a sedentary village lifestyle and were more reliant on agriculture to meet their subsistence needs. The exchange commodities binding Kisar to other island communities in a network of reciprocity would have been less essential after this time.

\section{ACKNOWLEDGEMENTS}

This research was funded through an ARC Laureate Fellowship to Sue O'Connor (FL120100156) and the Centre of Excellence for Australian Biodiversity and Heritage (CE170100015). The research in Indonesia was carried out on a FRP visa granted by RISTEK; O’Connor \#1456/FRP/SM/VII/2015.

\section{REFERENCES}

Agustiyanto, D. A., M. Suparman, E. Partoyo, and D. Sukarna. 1994. Peta Geologi Lembar Moa, Damar dan Bandanaira, Maluku. Bandung, Indonesia: Pusat Penelitian dan Pengembangan Geologi.

Ambrose, W.R., Allen, C., O’Connor, S., Spriggs, M., Oliveira, N.V., Reepmeyer, C., 2009. Possible obsidian sources for artefacts from Timor: narrowing the options using chemical data. Journal of Archaeological Science 36: 607-615.

Bayman, J.M., 2003. Stone adze economies in post-contact Hawai'i. In: Johnson, J.K., Bamforth, D., Nassaney, M.S., Odell, G.H., Carmody, M.L., Silliman, S.W., Bayman, J.M., Volmar, M.A., Cassell, M.S., Wagner, M.J., Ruggiero, D.A. 
(Eds.), Stone Tool Traditions in the Contact Era. University of Alabama Press Tuscaloosa, pp. 94-108.

Bellwood, P., G. Nitihaminoto, G. Irwin, Gunadi, A. Waluyo, and D. Tanudirjo. 1998. 35,000 years of prehistory in the Northern Moluccas. In: Bird's head approaches: Irian Jaya studies, a programme for interdisciplinary research, ed. G. Bartstra, Rotterdam and Brookfield: A. A. Balkema, pp. 233-75.

Bellwood, P., 2011. Holocene Population History in the Pacific Region as a Model for Worldwide Food Producer Dispersals. Current Anthropology 52: S363-S377.

Cashdan, E. 1985. Coping with risk: Reciprocity among the Basarwa of Northern Botswana. Man 20: 454-474.

Dawson, H. 2014. Mediterranean Voyages: The Archaeology of Island Colonisation and Abandonment. Walnut Creek, California: Left Coast Press.

Fitzpatrick, S. M., V. D. Thompson, A. S. Poteate, M. F. Napolitano, and J. M. Erlandson. 2016. Marginalization of the Margins: The Importance of Smaller Islands in Human Prehistory. The Journal of Island and Coastal Archaeology 11(2):155-170.

Glascock, M.D., Ferguson, J.R., 2012. Report on the Analysis of Obsidian Source Samples by Multiple Analytical Methods. University of Missouri Research Reactor, Columbia.

Hall, R. 2002. Cenozoic geological and plate tectonic evolution of SE Asia and the SW Pacific: computer-based reconstructions, model and animations. Journal of Asian Earth Sciences 20(4):353-431.

Hawkins, S., S. O'Connor, T. R. Maloney, M. Litster, S. Kealy, J. N. Fenner, K. Aplin, et al. 2017. Oldest human occupation of Wallacea at Laili Cave, Timor-Leste, 
shows broad-spectrum foraging responses to late Pleistocene environments. Quaternary Science Reviews 171:58-72.

Kealy, S., J. Louys and S. O’Connor 2018. Least-cost pathway models indicate northern human dispersal from Sunda to Sahul. Journal of Human Evolution 125:59-70.

Keegan, W.F., S.M. Fitzpatrick, K.S.,Sealey, M.J. LeFebvre, and P.T. Sinelli, 2008. The role of small islands in marine subsistence strategies: Case studies from the Caribbean. Human Ecology 36(5):635-654.

Lambeck, K., Rouby, H., Purcell, A., Sun, Y., Sambridge, M., 2014. Sea level and global ice volumes from the Last Glacial Maximum to the Holocene. Proceedings of the National Academy of Science USA 111: 15296-15303.

Major, J., R. Harris, H. W. Chiang, N. Cox, C. C. Shen, S. T. Nelson, C. Prasetyadi, and A. Rianto. 2013. Quaternary hinterland evolution of the active Banda Arc: Surface uplift and neotectonic deformation recorded by coral terraces at Kisar, Indonesia. Journal of Asian Earth Sciences 73:149-161.

Maloney, T., Mahirta, S. O’Connor and C. Reepmeyer 2018. Specialised lithic technology of terminal Pleistocene maritime peoples of Wallacea. Archaeological Research in Asia 16:78-87.

O’Connor, S., Mahirta, Kealy, S., Boulanger, C., Maloney, T., Hawkins, S., Langley, M.C., Kaharudin, H.A.F., Suniarti, Y., Husni, M., Marlon, R., Tanudirjo, D.A., Wattimena, L., Handoko, W., Alifah, Louys, J., 2018. Kisar and the Archaeology of Small Islands in the Wallacean Archipelago. Journal of Island Coastal and Archaeology 1-28.

Oppenheimer, S.J., 1998. Eden in the East: The Drowned Continent of Southeast Asia. Weidenfeld and Nicolson, London. 
Pawlik, A.F., Piper, P., Wood, R.E., Lim, K.K.A., Faylona, M.G.P.G., Mijares, A.S.B., Porr, M., 2015. Shell tool technology in Island Southeast Asia: an early Middle Holocene Tridacna adze from Ilin Island, Mindoro, Philippines. Antiquity 89: 292308.

Reepmeyer, C., S. O'Connor, and S. Brockwell. 2011. Long-term obsidian use in East Timor: Provenancing lithic artefacts from the Jerimalai cave. Archaeology in Oceania 46:85-90.

Reepmeyer, C., S. O'Connor, Mahirta, T. Maloney, and S. Kealy. 2016. Late Pleistocene/early Holocene maritime interaction in Southeastern Indonesia Timor Leste. Journal of Archaeological Science 76:21-30.

Samper Carro, S.C., O’Connor, S., Louys, J., Hawkins, S., Mahirta, M., 2016. Human maritime subsistence strategies in the Lesser Sunda Islands during the terminal Pleistocene early Holocene: New evidence from Alor, Indonesia. Quaternary International 416: 64-79..

Shipton, C., O’Connor, S., Reepmeyer, C., Kealy, S. in press. Shell Adzes, Exotic Obsidian, and Inter-Island Voyaging in the Terminal Pleistocene and Holocene of Wallacea. Journal of Island and Coastal Archaeology 0: 1-17.

Tanudirjo, D.A., 2005. Long-continuous or short-occasional occupation? The human use of Leang Sarru rockshelter in the Talaud Islands, Northeastern Indonesia. Bulletin of the Indo-Pacific Prehistory Association 25: 15-19.

Voris, H.K. 2000. Maps of Pleistocene sea levels in Southeast Asia: shorelines, river systems and time durations. Journal of Biogeography 27: 1153-1167.

Wiessner, P., 2002. Hunting, healing, and hxaro exchange: A long-term perspective on !Kung (Ju/'hoansi) large-game hunting. Evolution and Human Behavior 23: 407436. 
Woodroffe, C.D., Kennedy, D.M., Hopley, D., Rasmussen, C.E., Smithers, S.G., 2000.

Holocene reef growth in Torres Strait. Marine Geology 170: 331-346. 


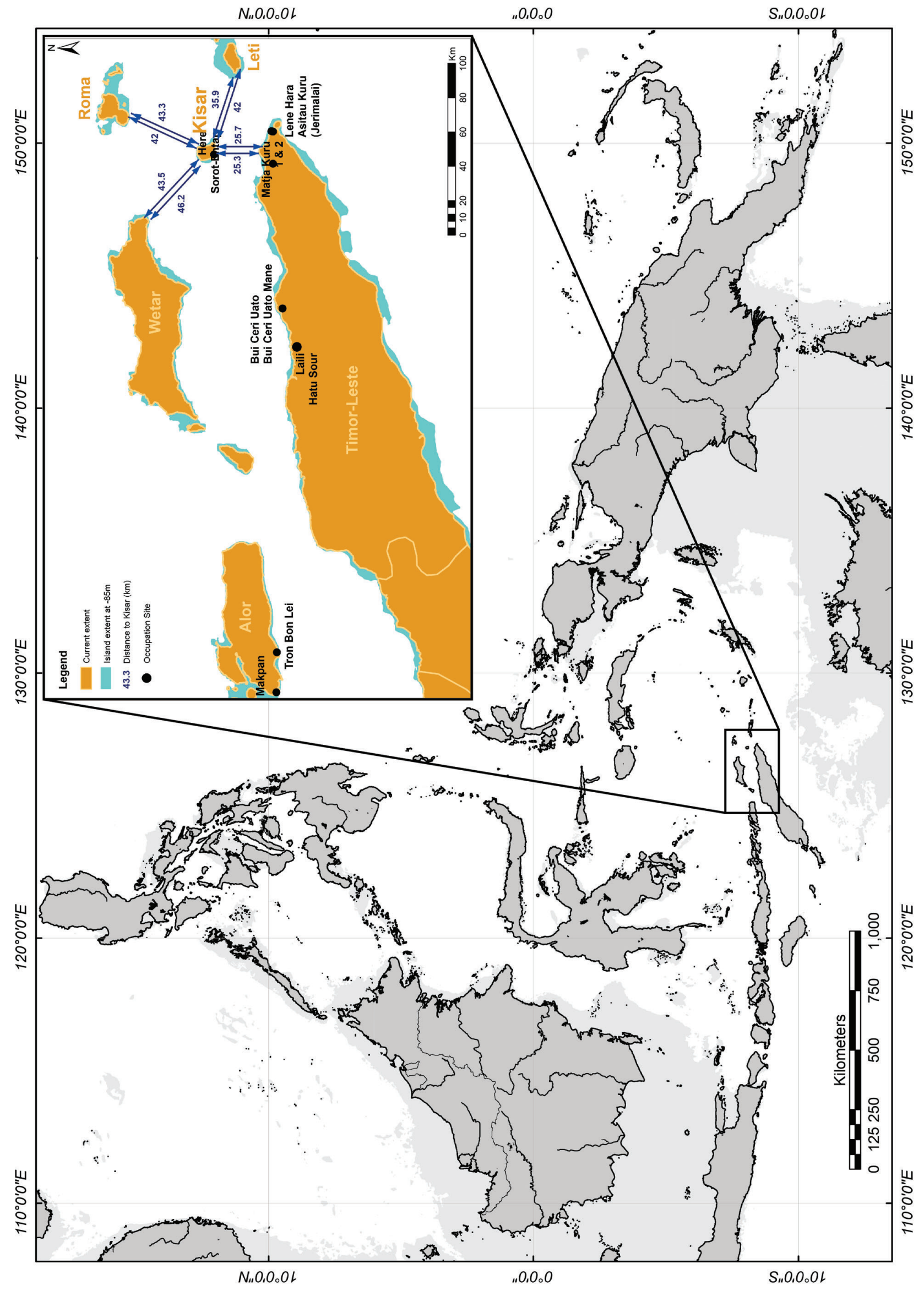




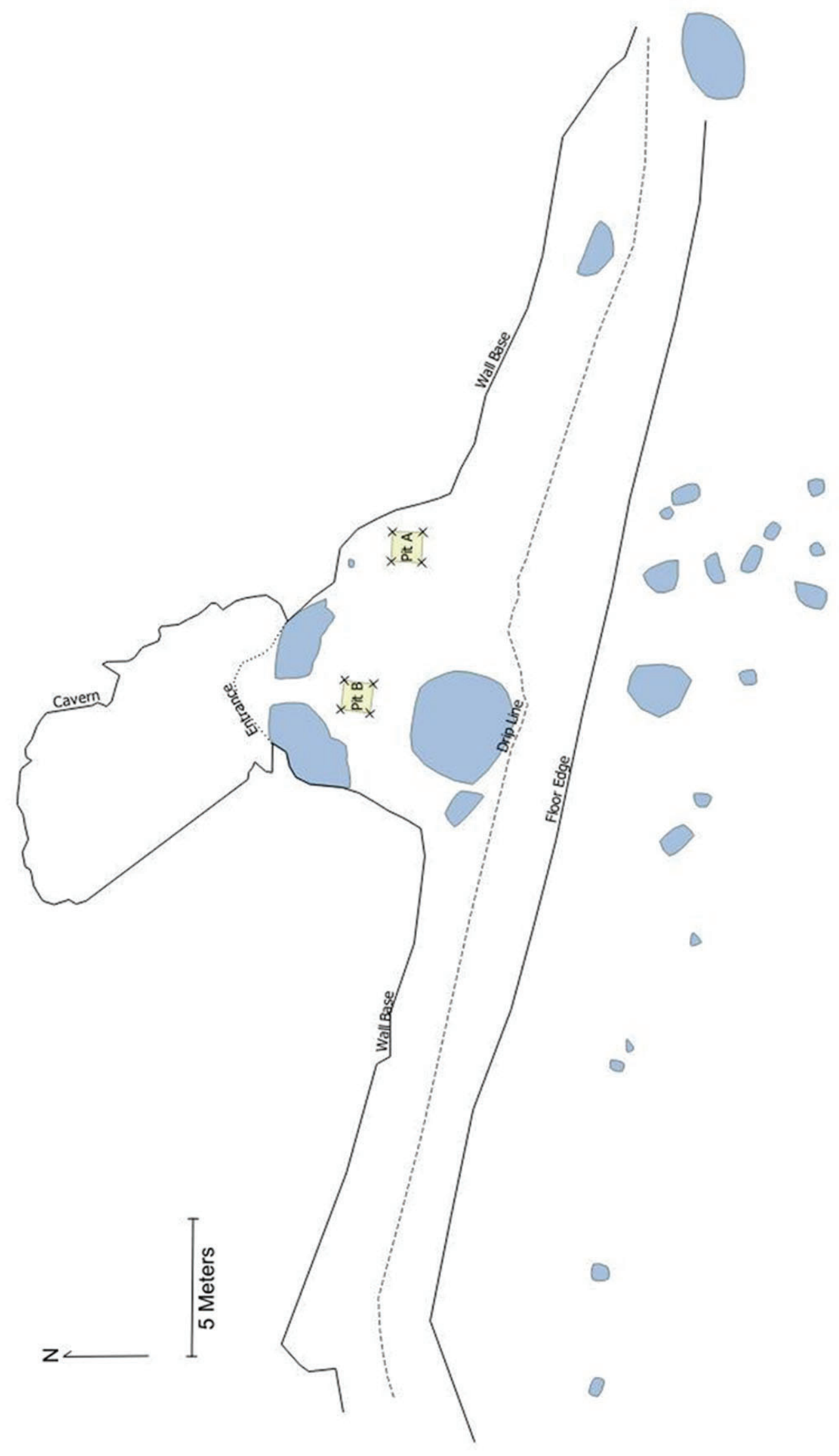




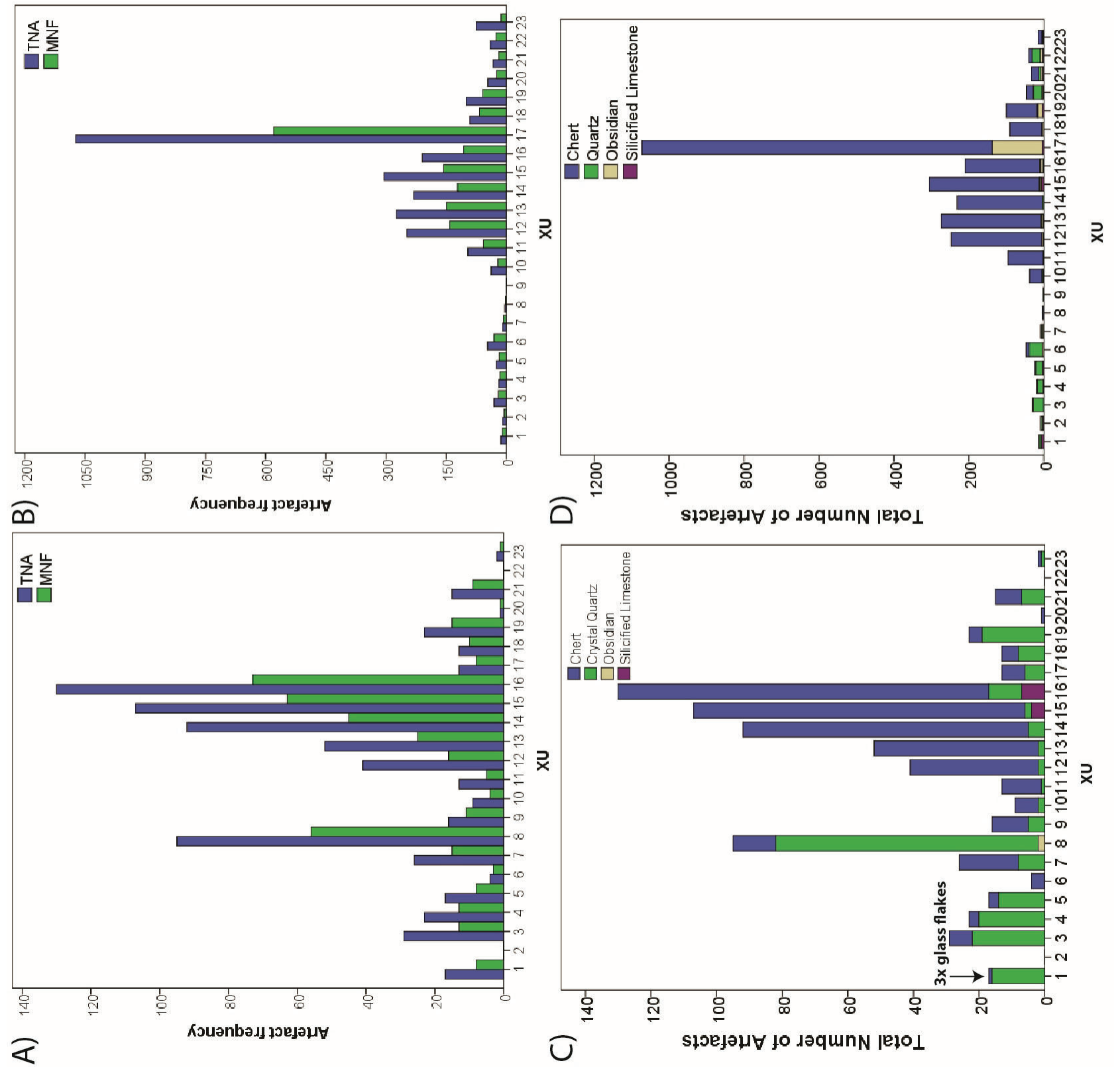


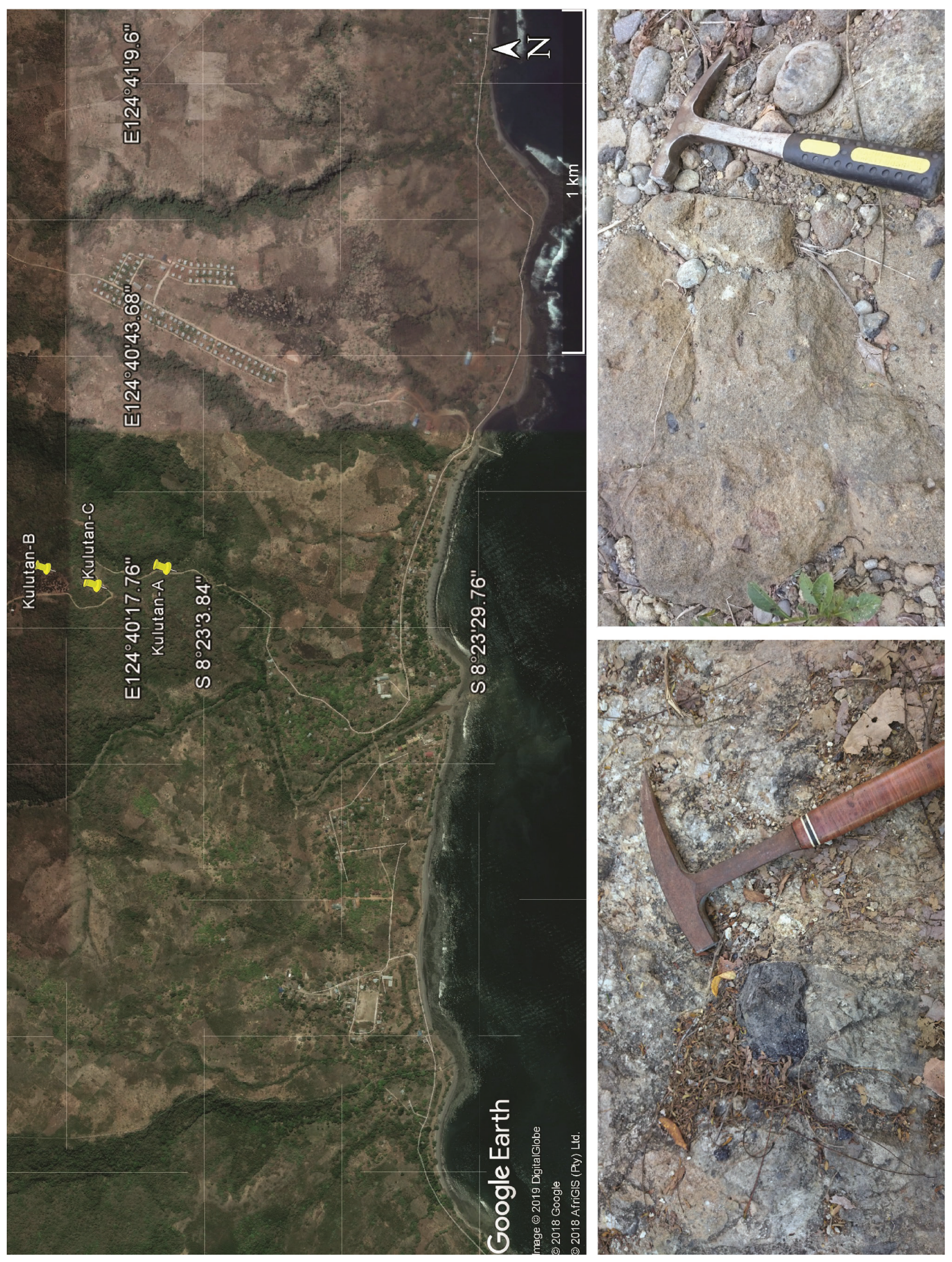




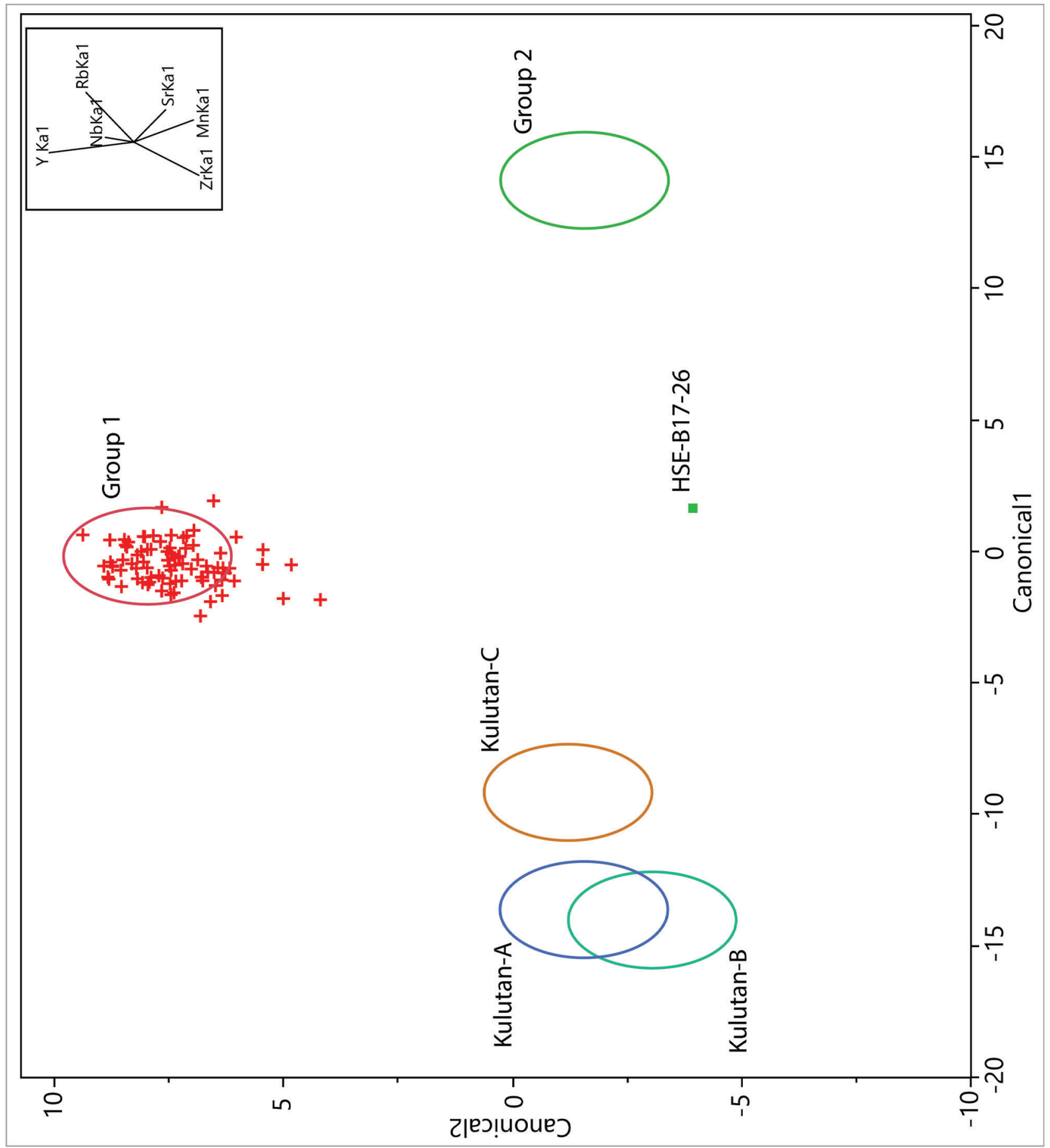

